\title{
EFFECTS OF CLOPIDOGREL IN ADDITION TO ASPIRIN IN PATIENTS WITH ACUTE CORONARY SYNDROMES WITHOUT ST-SEGMENT ELEVATION
}

\author{
The Clopidogrel in Unstable Angina to Prevent Recurrent Events Trial Investigators*
}

\begin{abstract}
Background Despite current treatments, patients who have acute coronary syndromes without ST-segment elevation have high rates of major vascular events. We evaluated the efficacy and safety of the antiplatelet agent clopidogrel when given with aspirin in such patients.

Methods We randomly assigned 12,562 patients who had presented within 24 hours after the onset of symptoms to receive clopidogrel $(300 \mathrm{mg}$ immediately, followed by $75 \mathrm{mg}$ once daily) (6259 patients) or placebo (6303 patients) in addition to aspirin for 3 to 12 months.
\end{abstract}

Results The first primary outcome - a composite of death from cardiovascular causes, nonfatal myocardial infarction, or stroke - occurred in 9.3 percent of the patients in the clopidogrel group and 11.4 percent of the patients in the placebo group (relative risk with clopidogrel as compared with placebo, 0.80; 95 percent confidence interval, 0.72 to $0.90 ; \mathrm{P}<0.001)$. The second primary outcome - the first primary outcome or refractory ischemia - occurred in 16.5 percent of the patients in the clopidogrel group and 18.8 percent of the patients in the placebo group (relative risk, 0.86 , $\mathrm{P}<0.001)$. The percentages of patients with in-hospital refractory or severe ischemia, heart failure, and revascularization procedures were also significantly lower with clopidogrel. There were significantly more patients with major bleeding in the clopidogrel group than in the placebo group (3.7 percent vs. 2.7 percent; relative risk, 1.38; $\mathrm{P}=0.001$ ), but there were not significantly more patients with episodes of life-threatening bleeding (2.1 percent vs. 1.8 percent, $\mathrm{P}=0.13$ ) or hemorrhagic strokes.

Conclusions The antiplatelet agent clopidogrel has beneficial effects in patients with acute coronary syndromes without ST-segment elevation. However, the risk of major bleeding is increased among patients treated with clopidogrel. (N Engl J Med 2001;345: 494-502.)

Copyright (c 2001 Massachusetts Medical Society.

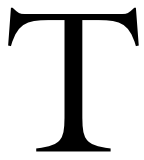
HROMBOSIS caused by a ruptured or eroded atherosclerotic plaque is the usual underlying mechanism of acute coronary syndromes. ${ }^{1}$ Aspirin and heparin reduce the risk of death from cardiovascular causes, new myocardial infarction, and recurrent ischemia, ${ }^{2,3}$ but there is still a substantial risk of such events in both the short term and the long term. Intravenous glycoprotein IIb/IIIa receptor blockers have been shown to reduce the incidence of early events, mainly among patients who are treated according to an invasive strategy, 4,5 but long-term oral therapy with glycoprotein IIb/IIIa receptor blockers is not beneficial and may even increase mortality. ${ }^{6}$ Similarly, continuing treatment with low-molecular-weight heparin beyond one week has not been shown to be effective. ${ }^{7}$ Although the longterm use of oral anticoagulants may be useful, no convincing evidence of their benefit is yet available. ${ }^{8}$ Therefore, there is a need to reduce further the risk of ischemic events in a broad spectrum of patients both when they first present with acute coronary syndromes and in the long term.

The thienopyridine derivatives, ticlopidine and clopidogrel, are antiplatelet agents that inhibit the platelet aggregation induced by adenosine diphosphate, thereby reducing ischemic events. ${ }^{9}$ Combining one of these drugs with aspirin, which blocks the thromboxane-mediated pathway, may have an additive effect. In patients who are undergoing percutaneous transluminal coronary angioplasty (PTCA) with stenting, shortterm aspirin treatment plus a thienopyridine derivative results in a substantially lower rate of myocardial infarction than does either aspirin alone or warfarin. ${ }^{10}$ However, the role of long-term combined therapy with aspirin and an antiplatelet agent in a broader group of patients at high risk for cardiovascular events is unknown. We therefore designed the Clopidogrel in Unstable Angina to Prevent Recurrent Events (CURE) trial to compare the efficacy and safety of the early and long-term use of clopidogrel plus aspirin with those of aspirin alone in patients with acute coronary syndromes and no ST-segment elevation.

\section{METHODS}

\section{Study Design}

We undertook a randomized, double-blind, placebo-controlled trial comparing clopidogrel with placebo in patients who presented with acute coronary syndromes without ST-segment elevation. The design and rationale of the study have been reported previously. ${ }^{9}$

\section{Study Patients}

Patients were eligible for the study if they had been hospitalized within 24 hours after the onset of symptoms and did not have ST-segment elevation. Initially, patients older than 60 years

The Manuscript Writing Committee (Salim Yusuf, D.Phil., F.R.C.P.C., Feng Zhao, M.Sc., Shamir R. Mehta, M.D., F.R.C.P.C., Susan Chrolavicius, B.Sc., Gianni Tognoni, M.D., and Keith K. Fox, M.D., F.R.C.P.) assumes responsibility for the overall content of the manuscript. Address reprint requests to Dr. Yusuf at the Canadian Cardiovascular Collaboration Project Office, Population Health Research Institute, McMaster University, Hamilton General Hospital, 237 Barton St. E., Hamilton, ON L8L 2X2, Canada, or at yusufs@mcmaster.ca.

*The Clopidogrel in Unstable Angina to Prevent Recurrent Events (CURE) trial investigators are listed in the Appendix. 
of age with no new electrocardiographic changes but with a history of coronary artery disease were included. However, after a review of the overall rates of events among the first 3000 patients, the steering committee recommended that we enroll only patients who had either electrocardiographic changes or an elevation in the serum level of cardiac enzymes or markers at entry. We excluded patients with contraindications to antithrombotic or antiplatelet therapy, those who were at high risk for bleeding or severe heart failure, those who were taking oral anticoagulants, and those who had undergone coronary revascularization in the previous three months or had received intravenous glycoprotein $\mathrm{IIb} / \mathrm{III}$ a receptor inhibitors in the previous three days.

After we had obtained written informed consent, patients were randomly assigned to either the clopidogrel group or the placebo group by a central, 24-hour, computerized randomization service. Permuted-block randomization, stratified according to clinical center, was used. A loading dose of clopidogrel $(300 \mathrm{mg}$ orally) or matching placebo was administered immediately, followed by clopidogrel (75 mg per day) or matching placebo for 3 to 12 months (mean duration of treatment, 9 months). Aspirin (recommended dose, 75 to $325 \mathrm{mg}$ daily) was started or continued simultaneously with the study drug. Follow-up assessments occurred at discharge, at one and three months, and then every three months until the end of the study.

\section{Study Organization}

Patients were recruited between December 1998 and September 2000 at 482 centers in 28 countries. The ethics review board at each institution approved the study. The study was organized and coordinated and all the data were managed and analyzed by the Canadian Cardiovascular Collaboration Project Office, McMaster University, Hamilton, Ontario. A steering committee consisting of national coordinators oversaw the study. The data were periodically reviewed by an independent data and safety monitoring board.

\section{Outcomes}

The first primary outcome was the composite of death from cardiovascular causes, nonfatal myocardial infarction, or stroke, and the second primary outcome was the composite of the first primary outcome or refractory ischemia. The secondary outcomes were severe ischemia, heart failure, and the need for revascularization. The safety-related outcomes were bleeding complications, which were categorized as life-threatening, major (requiring the transfusion of 2 or more units of blood), or minor. All primary outcomes and life-threatening and major bleeding complications were adjudicated by persons who were unaware of the patients' treatment-group assignments.

\section{Definitions}

Death from cardiovascular causes was defined as any death for which there was no clearly documented nonvascular cause. Myocardial infarction was defined by the presence of at least two of the following: ischemic chest pain; the elevation of the serum levels of cardiac markers or enzymes (troponin, creatine kinase, creatine kinase $\mathrm{MB}$ isoenzyme, or other cardiac enzymes) to at least twice the upper limit of the normal reference range or three times the upper limit of normal within 48 hours after percutaneous coronary intervention (or to a level 20 percent higher than the previous value if the level had already been elevated because of an early myocardial infarction); and electrocardiographic changes compatible with infarction. ${ }^{9}$ Stroke was defined as a new focal neurologic deficit of vascular origin lasting more than 24 hours. Stroke was further classified as the result of intracranial hemorrhage, ischemia (if a computed tomographic or magnetic resonance imaging scan was available), or uncertain cause.

Refractory ischemia in the hospital was defined as recurrent chest pain lasting more than five minutes with new ischemic electrocardiographic changes while the patient was receiving optimal medical therapy (two antianginal agents, one of which was intravenous nitrate unless such therapy was contraindicated) and leading to ad- ditional interventions (such as thrombolytic therapy, cardiac catheterization, the insertion of an intraaortic balloon pump, coronary revascularization, or transfer to a referral hospital for an invasive procedure) by midnight of the next calendar day. Refractory ischemia after discharge was defined by rehospitalization lasting at least 24 hours for unstable angina, with ischemic electrocardiographic changes. Severe ischemia (in the hospital) was defined as ischemia that was similar to in-hospital refractory ischemia but for which no urgent intervention was performed. Recurrent angina (in the hospital) was defined similarly, but electrocardiographic changes were not required.

Major bleeding episodes were defined as substantially disabling bleeding, intraocular bleeding leading to the loss of vision, or bleeding necessitating the transfusion of at least 2 units of blood. Major bleeding was classified as life-threatening if the bleeding episode was fatal or led to a reduction in the hemoglobin level of at least $5 \mathrm{~g}$ per deciliter or to substantial hypotension requiring the use of intravenous inotropic agents, if it necessitated a surgical intervention, if it was a symptomatic intracranial hemorrhage, or if it necessitated the transfusion of 4 or more units of blood. Minor bleeding episodes included other hemorrhages that led to the interruption of the study medication.

\section{Statistical Analysis}

The study was initially designed to include 9000 patients, with an expected rate of events in the placebo group of 12 to 14 percent. However, because the rate of events appeared to be lower than had originally been expected, the size of the study was increased. Assuming a rate of 10 percent in the placebo group for the first primary outcome and a two-sided alpha level of 0.045 , a study with 12,500 patients would have 90 percent power to detect a 16.9 percent reduction in risk. For the second primary outcome, assuming a 14 percent rate of events in the placebo group and a two-sided alpha level of 0.01 , the study had 90 percent power to detect a reduction of 16.4 percent in risk. Partitioning the alpha maintains an overall level of 0.05 , after adjustment for the overlap between the two sets of outcomes. All analyses were based on the intention-to-treat principle and used either the log-rank statistic or the chi-square test. Subgroup analyses were conducted with the use of tests for interactions in the Cox regression model.

The data and safety monitoring board monitored the incidence of the primary outcome to determine the benefit of clopidogrel, using a modified Haybittle-Peto boundary of 4 SD in the first half of the study and 3 SD in the second half of the study. The boundary had to be exceeded at two or more consecutive time points, at least three months apart, for the board to consider terminating the study early. There were two formal interim assessments performed at the times when approximately one third and two thirds of the expected events had occurred. Despite the fact that the preset boundary indicating efficacy had been crossed by the time of the second interim analysis, the board recommended that the trial continue until its planned end, in order to define more clearly whether the risks of major bleeding episodes could offset the benefits of therapy.

All unrefuted events that occurred up to the end of the scheduled follow-up period on December 6, 2000, are included in the analyses. Vital status was ascertained for 12,549 of the 12,562 patients who underwent randomization (99.9 percent), with 6 patients in the clopidogrel group and 7 in the placebo group lost to follow-up.

\section{RESULTS}

The base-line characteristics of the patients are shown in Table 1.

\section{Primary Outcomes}

The first primary outcome - death from cardiovascular causes, nonfatal myocardial infarction, or stroke - occurred in 582 of the 6259 patients in the clo- 
pidogrel group (9.3 percent) as compared with 719 of the 6303 patients in the placebo group (11.4 percent); relative risk, 0.80 ; 95 percent confidence interval, 0.72 to $0.90 ; \mathrm{P}<0.001$ ) (Fig. 1 and 2 and Table 2 ). The rate of the second primary outcome - death from cardiovascular causes, nonfatal myocardial infarction, stroke, or refractory ischemia - was also higher in the placebo group (1187 patients [18.8 percent]) than in the clopidogrel group (1035 patients [16.5 percent]; relative risk, 0.86 ; 95 percent confidence interval, 0.79 to $0.94 ; \mathrm{P}<0.001)$. The rate of each component of these composite outcomes also tended to be lower in the clopidogrel group. However, the clearest difference was observed in the rates of myocardial infarction (Table 2). With respect to refractory ischemia, the difference was observed primarily in first events that occurred during the initial hospitalization (85 in the clopidogrel group as compared with 126 in the placebo group; relative risk, $0.68 ; 95$ percent confidence interval, 0.52 to $0.90 ; \mathrm{P}=0.007$ ), with little difference in the rate of rehospitalization for unstable angina.

\section{Other In-Hospital Outcomes}

Significantly fewer patients in the clopidogrel group than in the placebo group had severe ischemia (176 patients [2.8 percent] vs. 237 patients [ 3.8 percent]; relative risk, $0.74 ; 95$ percent confidence interval, 0.61 to $0.90 ; \mathrm{P}=0.003)$ or recurrent angina ( 1307 [20.9 percent] vs. 1442 [22.9 percent]; relative risk, 0.91; 95 percent confidence interval, 0.85 to $0.98 ; \mathrm{P}=0.01$ ) (Fig. 3). Slightly fewer patients in the clopidogrel group underwent coronary revascularization during the study (36.0 percent vs. 36.9 percent), but the difference was accounted for entirely by a difference in the rate of revascularization during the initial period of hospitalization (20.8 percent in the clopidogrel group vs. 22.7 percent in the placebo group, $\mathrm{P}=0.03$ ). Radiologic evidence of heart failure was found in fewer patients in the clopidogrel group (229 [3.7 percent], vs. 280 [ 4.4 percent] in the placebo group; relative risk, $0.82 ; 95$ percent confidence interval, 0.69 to $0.98 ; \mathrm{P}=0.03$ ).

\section{Temporal Trends}

The rate of the first primary outcome was lower in the clopidogrel group both within the first 30 days after randomization (relative risk, $0.79 ; 95$ percent confidence interval, 0.67 to 0.92 ) and between 30 days and the end of the study (relative risk, $0.82 ; 95$ percent confidence interval, 0.70 to 0.95 ) (Fig. 1 and $2)$. Further analysis indicated that the benefit of clopidogrel was apparent within a few hours after randomization, with the rate of death from cardiovascular causes, nonfatal myocardial infarction, stroke, or refractory or severe ischemia significantly lower in the clopidogrel group by 24 hours after randomization (1.4 percent in the clopidogrel group vs. 2.1 percent in
Table 1. Base-Line Demographic Characteristics, Medical History, Electrocardiographic Changes, ANd DRUg Therapy.*

\begin{tabular}{|c|c|c|}
\hline ChARActeristic & $\begin{array}{l}\text { CLOPIDOGREL } \\
\text { GrouP } \\
\text { (N=6259) }\end{array}$ & $\begin{array}{l}\text { PLACEBo } \\
\text { GrouP } \\
\text { (N=6303) }\end{array}$ \\
\hline Age - yr & $64.2 \pm 11.3$ & $64.2 \pm 11.3$ \\
\hline Female sex - no. (\%) & $2420(38.7)$ & $2416(38.3)$ \\
\hline $\begin{array}{l}\text { Time from onset of pain to ran- } \\
\text { domization }-\mathrm{hr}\end{array}$ & $14.2 \pm 7.2$ & $14.1 \pm 7.1$ \\
\hline Heart rate - beats/min & $73.2 \pm 14.8$ & $73.0 \pm 14.6$ \\
\hline Systolic blood pressure $-\mathrm{mm} \mathrm{Hg}$ & $134.4 \pm 22.5$ & $134.1 \pm 22.0$ \\
\hline $\begin{array}{l}\text { Diagnosis at study entry }- \text { no. (\%) } \\
\text { Unstable angina } \\
\text { Suspected myocardial infarction }\end{array}$ & $\begin{array}{l}4690(74.9) \\
1569(25.1)\end{array}$ & $\begin{array}{l}4724(74.9) \\
1579(25.1)\end{array}$ \\
\hline $\begin{array}{l}\text { Associated myocardial infarction } \\
\quad-\text { no. }(\%) \dagger\end{array}$ & $1624(25.9)$ & $1659(26.3)$ \\
\hline $\begin{array}{l}\text { Medical history - no. }(\%) \\
\text { Myocardial infarction } \\
\text { CABG or PTCA } \\
\text { Stroke } \\
\text { Heart failure } \\
\text { Hypertension } \\
\text { Diabetes } \\
\text { Current or former smoker }\end{array}$ & $\begin{array}{c}2029(32.4) \\
1107(17.7) \\
274(4.4) \\
462(7.4) \\
3750(59.9) \\
1405(22.4) \\
3790(60.6)\end{array}$ & $\begin{array}{c}2015(32.0) \\
1139(18.1) \\
232(3.7) \\
492(7.8) \\
3642(57.8) \\
1435(22.8) \\
3841(60.9)\end{array}$ \\
\hline $\begin{array}{l}\text { Electrocardiographic abnormality } \\
\quad-\text { no. }(\%) \ddagger\end{array}$ & & \\
\hline $\begin{array}{l}\text { Any } \\
\text { ST segment }\end{array}$ & $5863(93.7)$ & $5921(93.9)$ \\
\hline $\begin{array}{l}\text { Depression } \geqslant 1 \mathrm{~mm} \\
\text { Elevation } \leqslant 1 \mathrm{~mm}\end{array}$ & $\begin{aligned} 2642(42.2) \\
203(3.2)\end{aligned}$ & $\begin{array}{c}2646(42.0) \\
199(3.2)\end{array}$ \\
\hline $\begin{array}{l}\text { Transient elevation }>2 \mathrm{~mm} \\
\text { T-wave inversion }\end{array}$ & $38(0.6)$ & $37(0.6)$ \\
\hline $\begin{array}{l}\text { Major }(\geqslant 2 \mathrm{~mm}) \\
\text { Other }(<2 \mathrm{~mm}) \\
\text { Other }\end{array}$ & $\begin{array}{r}1589(25.4) \\
721(11.5) \\
670(10.7)\end{array}$ & $\begin{array}{r}1635(25.9) \\
713(11.3) \\
690(10.9)\end{array}$ \\
\hline $\begin{array}{l}\text { Medications at time of randomiza- } \\
\text { tion }- \text { no. }(\%)\end{array}$ & & \\
\hline $\begin{array}{l}\text { Aspirin } \\
\text { Heparin or LMW heparin }\end{array}$ & $\begin{array}{l}4168(66.6) \\
4522(72.3)\end{array}$ & $\begin{array}{l}4134(65.6) \\
4605(73.1)\end{array}$ \\
\hline ACE inhibitor & $2347(37.5)$ & $2309(36.6)$ \\
\hline Beta-blocker & $3678(58.8)$ & $3690(58.5)$ \\
\hline Calcium-channel blocker & $1784(28.5)$ & $1771(28.1)$ \\
\hline Lipid-lowering agent & $1599(25.6)$ & $1586(25.2)$ \\
\hline Intravenous nitrate & $2836(45.3)$ & $2906(46.1)$ \\
\hline
\end{tabular}

*Plus-minus values are means $\pm S \mathrm{D}$. CABG denotes coronary-artery bypass grafting, PTCA percutaneous transluminal coronary angioplasty, LMW low molecular weight, and ACE angiotensin-converting enzyme.

†An associated myocardial infarction was defined as a myocardial infarction associated with the episode of pain that occurred before randomization.

$\ddagger$ Data on the particular type of abnormality were missing for one patient in the placebo group.

the placebo group; relative risk, 0.66 ; 95 percent confidence interval, 0.51 to 0.86 ).

\section{Subgroup Analyses}

The consistency of the results in a number of key subgroups is documented in Figure 4. The benefits were also consistent among subgroups receiving different doses of aspirin and among those receiving or not receiving lipid-lowering drugs, beta-blockers, heparin, or angiotensin-converting-enzyme inhibitors at 


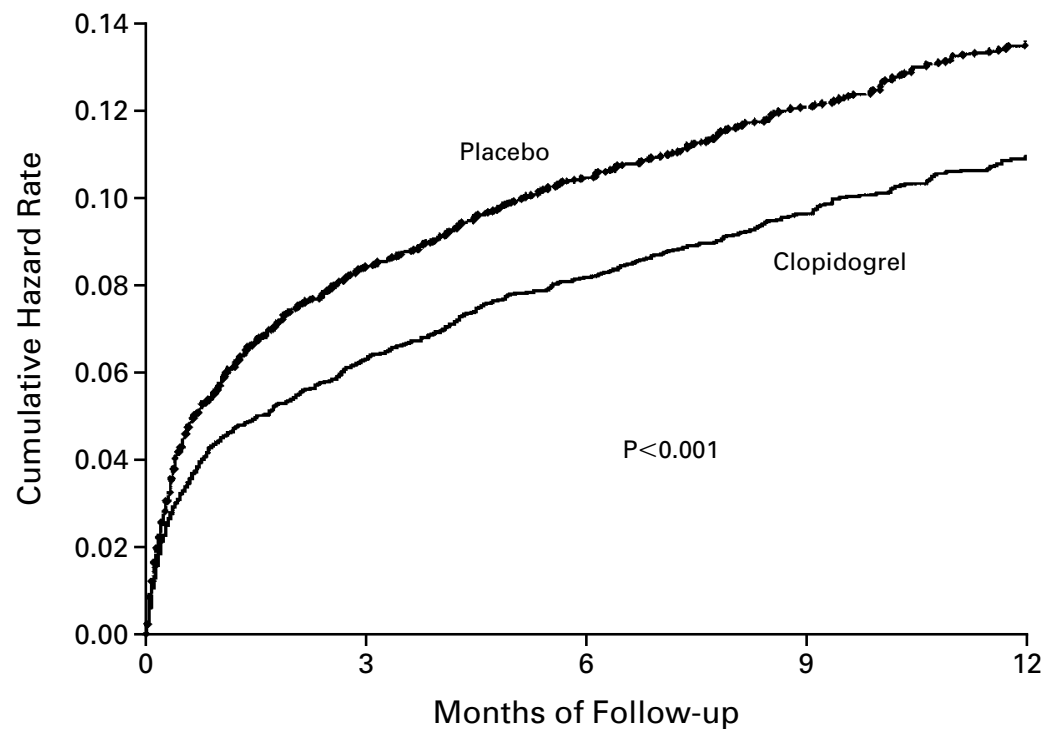

No. AT RISK

$\begin{array}{llllll}\text { Placebo } & 6303 & 5780 & 4664 & 3600 & 2388 \\ \text { Clopidogrel } & 6259 & 5866 & 4779 & 3644 & 2418\end{array}$

Figure 1. Cumulative Hazard Rates for the First Primary Outcome (Death from Cardiovascular Causes, Nonfatal Myocardial Infarction, or Stroke) during the 12 Months of the Study.

The results demonstrate the sustained effect of clopidogrel.

the time of randomization. There was a tendency toward a greater benefit among patients who had previously undergone revascularization (relative risk of the first primary outcome, $0.56 ; 95$ percent confidence interval, 0.43 to 0.72 ) than among those who had not (relative risk, 0.88 ; 95 percent confidence interval, 0.78 to 0.99 ; $\mathrm{P}$ for interaction $=0.002$ ). However, these results should be interpreted cautiously, given the large numbers of subgroup analyses that were performed. Furthermore, consistent benefits were observed irrespective of whether patients underwent revascularization procedures after randomization.

\section{Safety}

Major bleeding was significantly more common in the clopidogrel group (3.7 percent in the clopidogrel group as compared with 2.7 percent in the placebo group; relative risk, 1.38 ; 95 percent confidence interval, 1.13 to $1.67 ; \mathrm{P}=0.001$ ) (Table 3 ). There were 135 patients with life-threatening bleeding episodes in the clopidogrel group (2.2 percent) as compared with 112 in the placebo group (1.8 percent; relative risk, 1.21 ; 95 percent confidence interval, 0.95 to 1.56). There was no excess rate of fatal bleeding, bleeding requiring surgical intervention, or hemorrhagic stroke. The excess major bleeding episodes were gastrointestinal hemorrhages and bleeding at the sites of

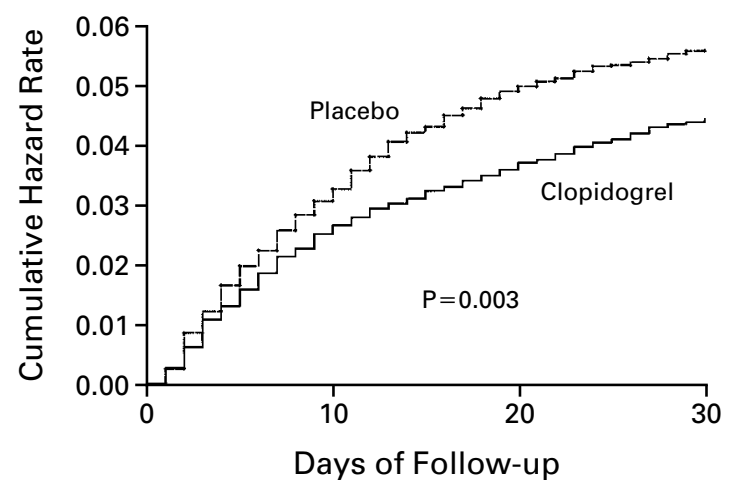

No. AT RISK

$\begin{array}{lllll}\text { Placebo } & 6303 & 6108 & 5998 & 5957\end{array}$

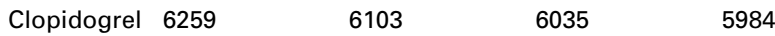

Figure 2. Cumulative Hazard Rates for the First Primary Outcome (Death from Cardiovascular Causes, Nonfatal Myocardial Infarction, or Stroke) during the First 30 Days after Randomization. The results demonstrate the early effect of clopidogrel. 
Table 2. Incidence of the Main Study Outcomes.*

\begin{tabular}{|c|c|c|c|c|}
\hline OUtсоме & $\begin{array}{l}\text { CLOPIDOGREL } \\
\text { Group } \\
(\mathrm{N}=6259)\end{array}$ & $\begin{array}{c}\text { Placebo } \\
\text { Group } \\
(\mathbf{N}=6303)\end{array}$ & $\begin{array}{c}\text { RELATIVE RISK } \\
(95 \% \mathrm{CI})\end{array}$ & P VALUE \\
\hline & \multicolumn{2}{|c|}{ no. $(\%)$} & & \\
\hline $\begin{array}{l}\text { First primary outcome: nonfatal myo- } \\
\text { cardial infarction, stroke, or } \\
\text { death from cardiovascular } \\
\text { causes }\end{array}$ & $582(9.3)$ & $719(11.4)$ & $0.80(0.72-0.90)$ & $<0.001$ \\
\hline $\begin{array}{l}\text { Second primary outcome: first } \\
\text { primary outcome or } \\
\text { refractory ischemia }\end{array}$ & $1035(16.5)$ & $1187(18.8)$ & $0.86(0.79-0.94)$ & $<0.001$ \\
\hline Death from cardiovascular causes & $318(5.1)$ & $345(5.5)$ & $0.93(0.79-1.08)$ & \\
\hline Myocardial infarction $\dagger$ & $324(5.2)$ & $419(6.7)$ & $0.77(0.67-0.89)$ & \\
\hline Q-wave & $116(1.9)$ & $193(3.1)$ & $0.60(0.48-0.76)$ & \\
\hline Non-Q-wave & $216(3.5)$ & $242(3.8)$ & $0.89(0.74-1.07)$ & \\
\hline Stroke & $75(1.2)$ & $87(1.4)$ & $0.86(0.63-1.18)$ & \\
\hline Refractory ischemia & $544(8.7)$ & $587(9.3)$ & $0.93(0.82-1.04)$ & \\
\hline During initial hospitalization & $85(1.4)$ & $126(2.0)$ & $0.68(0.52-0.90)$ & \\
\hline After discharge & $459(7.6)$ & $461(7.6)$ & $0.99(0.87-1.13)$ & \\
\hline Death from noncardiovascular causes & $41(0.7)$ & $45(0.7)$ & $0.91(0.60-1.39)$ & \\
\hline
\end{tabular}

* The number of patients who died from cardiovascular causes or had a nonfatal myocardial infarction was 539 (8.6 percent) in the clopidogrel group and 660 (10.5 percent) in the placebo group $(\mathrm{P}<0.001$; relative risk, 0.81 ; 95 percent confidence interval, 0.72 to 0.91$)$. The corresponding numbers at 30 days were 241 (3.9 percent) and 305 (4.8 percent) (relative risk, 0.79; 95 percent confidence interval, 0.67 to $0.94 ; \mathrm{P}=0.007)$. CI denotes confidence interval.

†Some patients had both a $\mathrm{Q}$-wave and a non-Q-wave myocardial infarction.

‡Only the first ischemic event was counted for each patient.

arterial punctures. The number of patients who required the transfusion of 2 or more units of blood was higher in the clopidogrel group (177 [2.8 percent]) than in the placebo group (137 [2.2 percent], $\mathrm{P}=$ $0.02)$. The rate of major bleeding episodes was higher early (within 30 days after randomization: 2.0 percent vs. 1.5 percent; relative risk, 1.31 ; 95 percent confidence interval, 1.01 to 1.70 ) and also late (more than 30 days after randomization: 1.7 percent vs. 1.1 percent; relative risk, 1.48; 95 percent confidence interval, 1.10 to 1.99 ). Overall, there was no significant excess of major bleeding episodes after coronary-artery bypass grafting $(\mathrm{CABG})$ (1.3 percent vs. 1.1 percent; relative risk, $1.26 ; 95$ percent confidence interval, 0.93 to 1.71). However, in most patients scheduled for CABG surgery, the study medication was discontinued before the procedure (median time before the procedure, five days). In the 910 patients in whom the study medication was discontinued more than five days before the procedure (five days being the duration of the effect of clopidogrel), there was no apparent excess of major bleeding within seven days after surgery (4.4 percent of the patients in the clopidogrel group vs. 5.3 percent of those in the placebo group). In the 912 patients who stopped taking the medications within five days before CABG surgery, the rate of major bleeding was 9.6 percent in the clopidogrel group and 6.3 percent in the placebo group (relative risk, 1.53;
$\mathrm{P}=0.06)$. Overall, the risk of minor bleeding was significantly higher in the clopidogrel group than in the placebo group (322 [5.1 percent] vs. 153 [2.4 percent $] ; \mathrm{P}<0.001)$. The numbers of patients with thrombocytopenia ( 28 in the placebo group and 26 in the clopidogrel group) or neutropenia (5 and 8 , respectively) were similar.

\section{Adherence to Study Medication and Aspirin}

A total of 46.2 percent of the patients in the clopidogrel group discontinued the study medication temporarily (for more than five days), as compared with 45.4 percent in the placebo group. The most common reason for the temporary discontinuation of the study medication was the need for revascularization or another surgical procedure; 84 percent of the patients with such a need discontinued the medication before the procedure. A total of 21.1 percent of the patients in the clopidogrel group discontinued the study medication permanently, as compared with 18.8 percent in the placebo group. A total of 99 percent of the patients in both groups were taking aspirin while they were in the hospital, 96 percent were taking it at three months, and 94 percent at the final visit. The use of all other medications (other than thrombolytic therapy and glycoprotein IIb/IIIa receptor inhibitors) was similar in the clopidogrel group and the placebo group. 


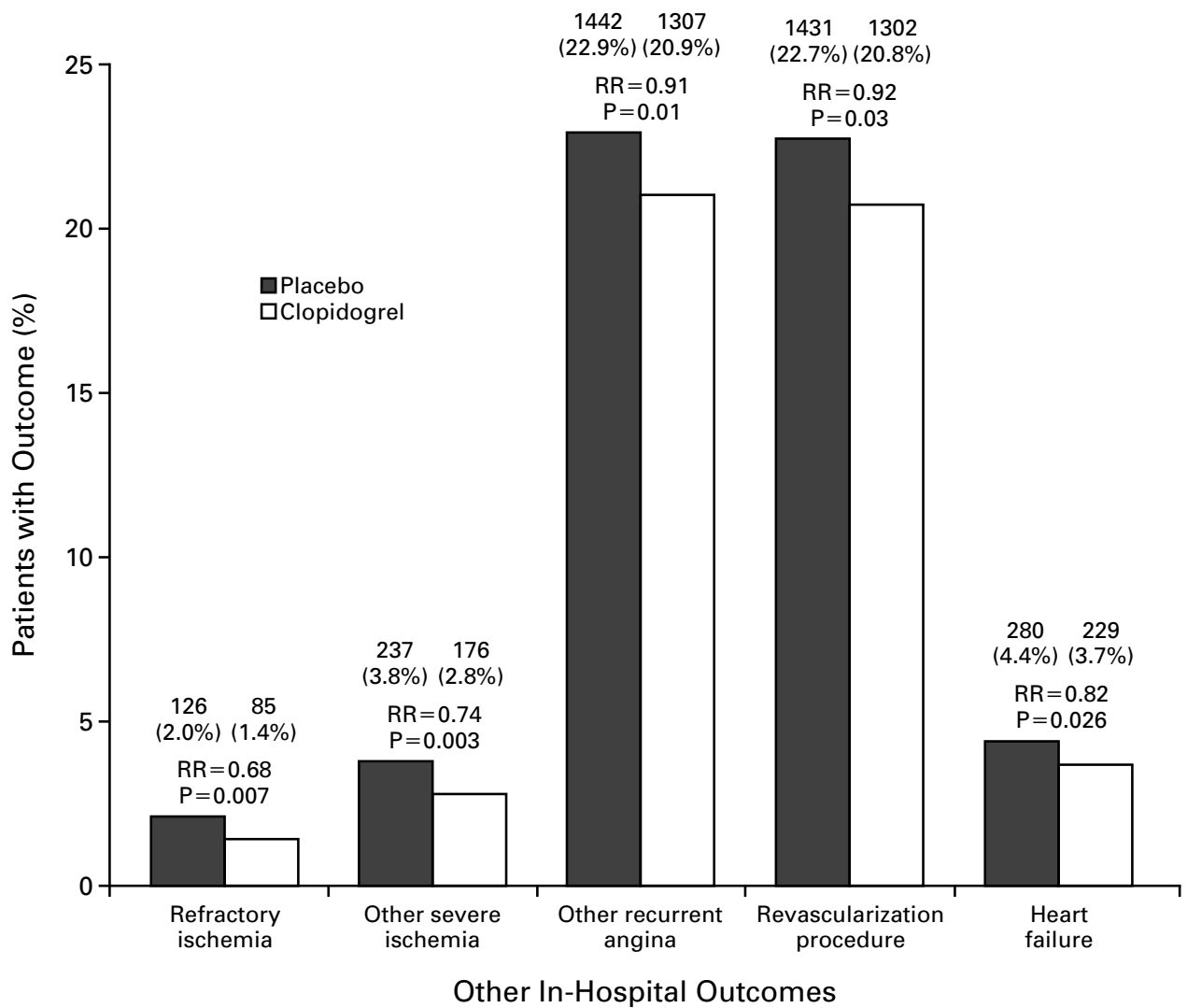

Figure 3. Proportions of Patients Who Had Events Other Than Those Included in the First Primary Outcome while They Were in the Hospital.

The numbers and percentages of patients in each group with the specified outcome are given above the bars. RR denotes relative risk.

\section{Thrombolytic Therapy and Glycoprotein Ilb/IIla Receptor Inhibitors}

A total of 71 patients in the clopidogrel group (1.1 percent) and 126 patients in the placebo group $(2.0$ percent) received thrombolytic therapy (relative risk, 0.57 ; 95 percent confidence interval, 0.43 to 0.76 ; $\mathrm{P}<0.001) ; 369$ patients in the clopidogrel group (5.9 percent) and 454 in the placebo group (7.2 percent) received a glycoprotein IIb/IIIa receptor inhibitor (relative risk, $0.82 ; 95$ percent confidence interval, 0.72 to $0.93 ; \mathrm{P}=0.003)$.

\section{DISCUSSION}

Our study demonstrates the benefit of adding clopidogrel to the regimen of treatment for patients with acute coronary syndromes without ST-segment elevation who are receiving aspirin and other medications. Treatment with clopidogrel reduced the risk of myocardial infarction and recurrent ischemia, with a trend toward lower rates of stroke and death from cardiovascular causes. Fewer patients in the clopidogrel group received a thrombolytic agent or an intravenous gly- coprotein IIb/IIIa receptor inhibitor. The benefits we observed were in addition to those of aspirin, which was recommended for all patients, indicating that blocking the adenosine diphosphate-receptor pathway with clopidogrel leads to further benefit.

Our study primarily included centers in which there was no routine policy of early use of invasive procedures, since such a policy would have led to a high rate of immediate discontinuation of the study medication and the use of an open-label thienopyridine derivative. Once a patient had been randomly assigned to a treatment group, there were no restrictions on the use of any therapy or intervention. In particular, if the clinician believed that angiography and revascularization were needed or that a thienopyridine derivative was indicated, the study medication could be stopped or open-label clopidogrel or ticlopidine could be used. In fact, 5491 patients (43.7 percent) underwent angiography, 2072 patients (16.5 percent) underwent $\mathrm{CABG}$, and 2658 patients (21.2 percent) underwent PTCA. In 85.8 percent of the patients who underwent PTCA and 84.9 percent of those who underwent 


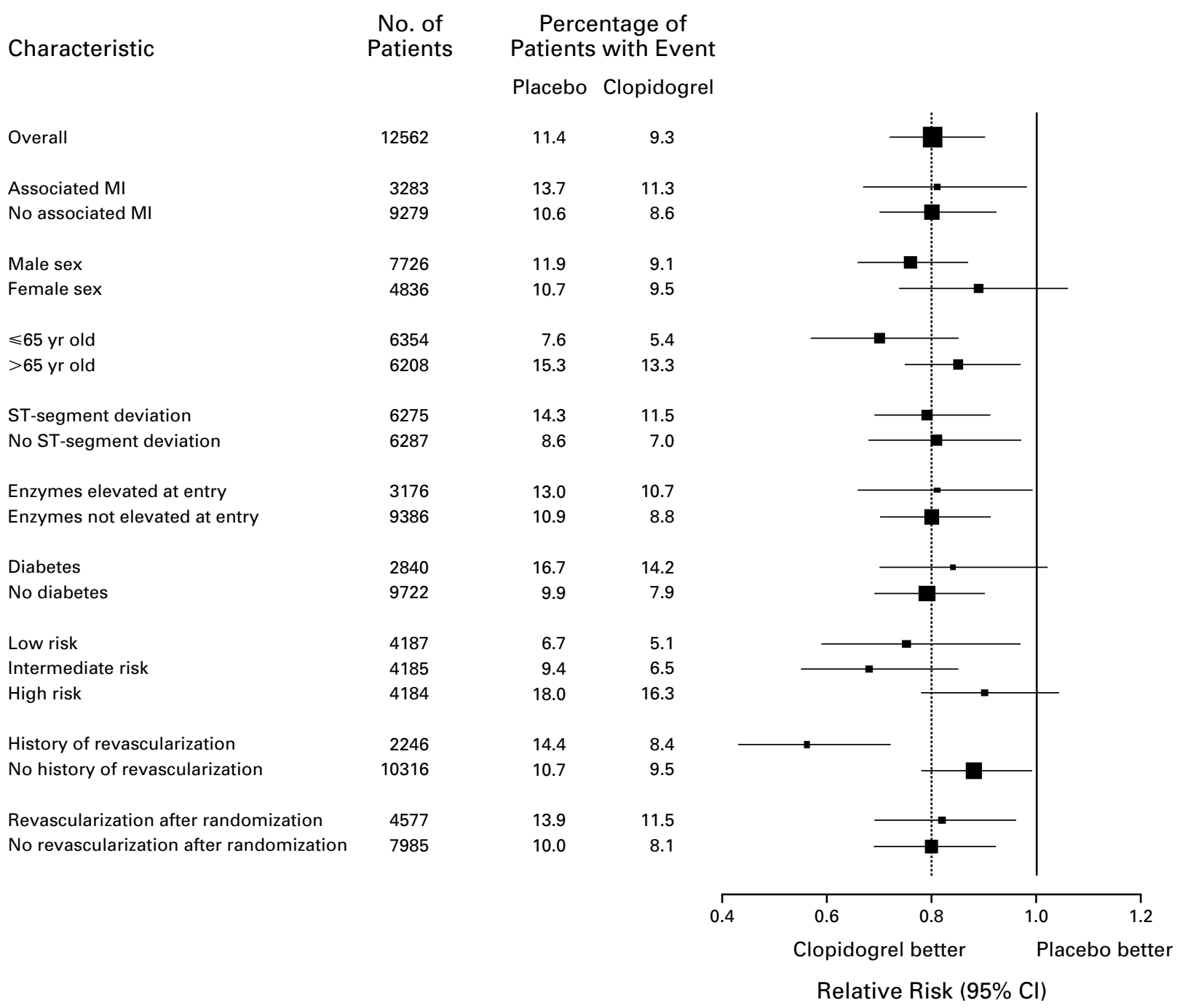

Figure 4. The Rates and Relative Risks of the First Primary Outcome (Death from Cardiovascular Causes, Nonfatal Myocardial Infarction, or Stroke) in Various Subgroups.

The data show the consistency of the benefit of clopidogrel. The dotted line represents the average treatment effect. The size of each box is proportional to the number of patients in the individual analysis. An associated myocardial infarction (MI) was defined as a myocardial infarction associated with the episode of pain that occurred before randomization. Because of missing data, six patients could not be classified in a risk category. $\mathrm{Cl}$ denotes confidence interval.

CABG, the use of the study medication was temporarily interrupted for more than five days, and the vast majority of the patients who underwent PTCA received a thienopyridine-type antiplatelet agent for about two to four weeks. In the patients who underwent CABG, the study medication was restarted after a median of 11 days. Although these interruptions of therapy with the study medication would tend to result in an underestimate of the difference between the clopidogrel group and the placebo group, they also permit us to make useful estimates of the benefits and risks of clopidogrel when it is used routinely and over the long term, as compared with a strategy of more selective and short-term use among those undergoing implantation of a coronary stent.

Clopidogrel prevented a range of ischemic coronary events - among them, myocardial infarction and severe and refractory ischemia. Clopidogrel was associated with a trend toward fewer ischemic strokes, and there was no increase in the rate of hemorrhagic stroke that would offset these benefits. There was a significant reduction in the incidence of heart failure with clopidogrel that was of about the same magnitude as the reduction in the incidence of ischemic events, suggesting that the reduction of ischemia can prevent heart failure. The benefits of clopidogrel were observed in 
Table 3. Bleeding Complications.*

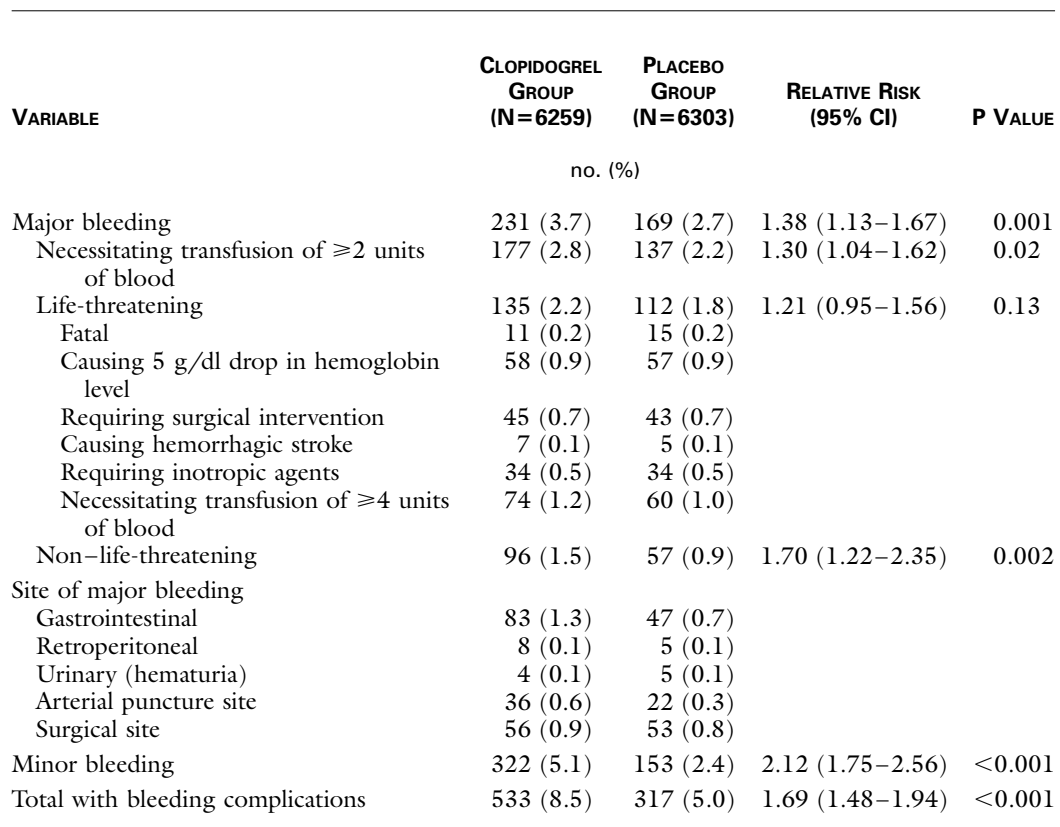

*The number of patients with bleeding that met the criteria for major bleeding established by the Thrombolysis in Myocardial Infarction trial ${ }^{11}$ was 68 in the clopidogrel group and 73 in the placebo group (relative risk, $0.94 ; 95$ percent confidence interval, 0.68 to $1.30 ; \mathrm{P}=0.70$ ). The number with bleeding that met the criteria for life-threatening or severe bleeding established by the Global Utilization of Streptokinase and Tissue Plasminogen Activator for Occluded Coronary Arteries trial ${ }^{12}$ was 78 in the clopidogrel group and 70 in the placebo group (relative risk, $1.12 ; 95$ percent confidence interval, 0.81 to $1.55 ; \mathrm{P}=0.48$ ). Some patients had more than one bleeding episode. CI denotes confidence interval.

a range of patients, including both patients who were undergoing revascularization procedures and those who were not. The benefits were also observed in those at low, medium, and high risk of cardiovascular events and those who were receiving various proven therapies such as aspirin, lipid-lowering drugs, angiotensin-converting-enzyme inhibitors, and betablockers. ${ }^{13-16}$ The benefits of clopidogrel were apparent as early as the first 24 hours after randomization, indicating that the oral loading dose was rapidly effective. Thereafter, the differences between the two groups were maintained until the end of the study.

Clopidogrel increased the risk of minor and major bleeding episodes. For every 1000 patients treated with clopidogrel, 6 will require a transfusion. However, there was no excess in bleeding that caused strokes, required surgical intervention or inotropic agents, or caused permanent disability. Furthermore, the excess risk of bleeding we observed is similar to that observed with aspirin alone, as compared with a control, in previous studies and lower than that observed in most trials of the short-term intravenous use or the prolonged oral use of glycoprotein IIb/IIIa receptor inhibitors. 4,16,17 The risk of bleeding may have been partly mitigated by the temporary discontinuation of the study medication before surgery. Treatment with clo- pidogrel was not associated with an excess rate of any other type of adverse event that necessitated the discontinuation of the study drug; this finding indicates that the combination of clopidogrel and aspirin is as well tolerated as aspirin alone.

In summary, clopidogrel significantly reduces the risk of the composite outcome of death from cardiovascular causes, nonfatal myocardial infarction, or stroke, as well as a range of related ischemic events. The use of the drug, in addition to aspirin, is associated with an increased risk of bleeding.

Supported by Sanofi-Synthelabo and Bristol-Myers Squibb. Dr. Yusuf is the recipient of a Senior Scientist award from the Canadian Institutes of Health Research and holds an endowed chair from the Heart and Stroke Foundation of Ontario. Dr. Mehta is a research fellow of the Heart and Stroke Foundation of Canada.

Drs. Yusuf, Mehta, Tognoni, and Fox have received honorariums for educational activities or have served as consultants to Bristol-Myers Squibb and Sanofi-Synthelabo.

We are indebted to Judy Lindeman for secretarial assistance.

\section{APPENDIX}

The following persons participated in the CURE trial: Steering Committee: S. Yusuf (chair and principal investigator), K.A.A. Fox (cochair), G. Tognoni (cochair), S.R. Mehta (project officer), S. Chrolavicius (study coordinator), S. Anand, A. Avezum, N. Awan, M. Bertrand, A. Budaj, L. 
Ceremuzynski, J. Col, PJ Commerford, R. Diaz, M. Flather M-G. Franzosi, B. Gersh, W. Grossman, D.A. Halon, D. Hunt, C. Joyner (chair of the Events Adjudication Committee), N. Karatzas, M. Keltai, S. Kopecky, B.S. Lewis, A. Maggioni, K. Malmberg, T. Moccetti, J. Morais, M. Natarajan, E. Paolasso, R. Peters, L. Piegas, A. Pipilis, J. Pogue, M. RamosCorrales, H.-J. Rupprecht, E. Sitkei, V. Valentin, J. Varigos, P. Widimsky, T. Wittlinger, M. Blumenthal, J. Bouthier, C. Gaudin, T. Hess, N. Khurmi, M. Sotty; Canadian Cardiovascular Collaboration (CCC) Project Office: I. Copland, B. Cracknell, C. Demers, J. Eikelboom, B. Morris, J. Pasquale, V. Yacyshyn, F. Zhao; Data Safety and Monitoring Board: G. Wyse (chair), J. Cairns, R. Hart, J. Hirsh, M. Gent, T. Ryan, J. Wittes; Investigators who recruited more than 10 patients (the numbers of patients appear in parentheses): Argentina (512) - R. Ahuad Guerrero, V. Arias, F.H. Bello, J.O. Bono, L. Bujan, A. Caccavo, A.A. Fernandez, J.J. Fuselli, A.J. Gambarte, E.G. Hasbani, E. Marzetti, G. Mon, R. Nordaby, G. Quijano, A. Salvati, E. San Martin, P. Schygiel, A. Sosa Liprandi, H. Torre, E. Tuero; Australia (742) - J. Amerena, J.H.N. Bett, J. Botha, A. Buncle, D. Careless, A. Ewart, A. Fagan, D. Fitzpatrick, P. Garrahy, K. Gunawardane, A. Hamer, A. Hill, N. Jepson, G. Lane, H. LeGood, G. Nelson, M. Sallaberger, G. Tulloch, D. Owensby, J. Padley, D. Rees, K. Roberts, D. Rosen, J. Sampson, B. Singh, C. Singh, R. Taylor, A. Thomson, W. Walsh; Austria (5); Belgium (38) - H. De Raedt, J. Rankin; Brazil (598) - J.A. Abrantes, D.C. de Albuquerque, C. Blacher, L.C. Bodanese, A.C. Carvalho, M. Coutinho, O. Dutra, J.P. Esteves, P. Leães, N.S. Lima, N. Lobo, J.A. Marin Neto, R.L. Marino, J.C. Nicolau, R.C. Pedrosa, I. Pereira Filho, W. Rabelo, A. Rabelo Jr., R.F. Ramos, R.M. Rocha, E.C. Schramm, C.V. Serrano, Jr., V.P. Souza, A. Timerman, R. Vaz, S.S. Xavier; Canada (1761) - P. Auger, K. Barbin, I. Bata, L. Bergeron, R.K. Bhargava, P. Bogaty, P. Bolduc, T. Boyne, L. Boyer, B. Bozek, T. Calmusky, Y.K. Chan, D. Cole, M. D'Astous, M. David, T. Davies, L. Desjardins, F.C. Dohaney, M. Doody, F. Dumont, C. Fortin, A. Fung, G. Galdreault, P.B. Gervais, J.P. Giannoccaro, G. Gosselin, D. Grandmont, A. Grover, M. Gupta, H. Hink, J.G. Hiscock, D. Hutton, J.W.H. Hynd, A. Iless, C. Kent, A. Kitching, S. Kouz, K. Kwok, M. LaForest, H. Lee, C. Lefkowitz, B. Lubelsky, P. Ma, J.-F. Marquis, A. McCallum, R. Major, B. May, M. Mercier, M. Montigny, A. Morris, S. Nawaz, J. Norris, S. Pallie, A. Panju, P. Parekh, C. Patterson, Y. Pesant, C. Pilon, A.R.J. Rajakumar, T. Rebane, J. Ricci, M. Ruel, R. Schuld, R. Starra, M. Thornley, A.S. Weeks, L.H. Winkler, G. Wisenberg, I. Witt, K. Woo, E. Yu, R. Zadra, D. Zaniol; Czech Republic (165) - P. Bocek, M. Branny, V. Cepelak, P. Gregor, L. Groch, P. Jansky, P. Svitil, A. Vaclavicek; Denmark (40) - S. Husted, B. Ziegler; Finland (161) - A. Karhu, J. Mustonen, M. Nieminen, K. Nissinen, K. Peuhkurinen, P. Tuomainen, A. Ylitalo; France (360) - M. Adam, G. Amat, K. Asward, G. Bessede, P. Dambrine, E. Decoulx, B. D'Hautefeuille, J. Dujardin, R. Fouche, P. Fournier, Y. Haftel, J.Y. Ketelers, R. Lallemant, M. Lang, F. Leroy, M. Richard; Germany (778) - W. Dippold, J. Gronholz, J. Harenberg, C. Hilpert, T. Horacek, A. Moritz, H. Neuss, K. Nitsche, H.R. Ochs, M. Plumer-Schmidt, B. Pollock, G. Post, M. Sauer, A. Schmidt, H. Schmitt, H.-O. Schulze, P. Schuster, E.-R. von Leitner; Greece (144) - S. Christakos, K. Karidis, K. Kifnidis, K. Papadopoulos, D. Symconidis, A. Tirologos; Hungary (599) - B. Garai, T. Gesztesi, K. Heltai, B. Herczeg, A. Janosi, A. Kadar, E. Kalo, P. Karpati, B. Kiss, A. Nagy, M. Okros, F. Poor, L. Regos, J. Sebo, E. Sitkei, P. Soltesz, J. Stefan, F. Szaboki, S. Timar, Z. Varallyay, K. Veres; Ireland (37) - K. Daly; Israel (694) G. Cotter, A. Marmor, D. Nazzal, M. Omary, L. Reisin, T. Rosenfeld, M. Shargorodsky, S. Shasha, A. Smulovitz, Z. Vered, R. Zimlichman; Italy (538) - G. Beria, D. Bernardi, E. Bonfanti, V. Ceci, R. De Caterina, S. De Servi, M. DelPinto, A. Di Chiara, G. Di Pasquale, L. Filippucci, M. Galli, E. Gardinale, M.T. Landoni, A. Martoni, F. Mauri, N. Maurea, P. Meneghetti, M. Mennuni, A. Murrone, A. Pani, E. Paolini, P. Passarelli, G. Pettinati, B. Pontillo, L. Rossi, R. Rossi, M. Santini, G. Sabino, P. Tricoci, F.M. Turazza; Mexico (240) - A. Cruz Diaz, A. Garcia-Sosa, I. Hernandez Santamaria, J. Leiva Pons, J.N. Medecigo, F.J. Rangez Rojo, C. JorgesSanchez Diaz, J. Trujillo Castro, E. Villegas Morales; the Netherlands (499) - S. Baldew, D.C.G. Basart, N. Bijsterfeld, P. Bronzwaer, A. Chardon, M. den Hartoog, H. Heijmen, J. Heijmeriks, G. Jochemsen, H. Klomps, P. Landsaat, H. Michels, A. Moons, M. Pieterse, A. Sadée, G. van Beek, M. Van Hessen, J. Verheul, E. Viergever; New Zealand (89) - M. Audeau, M. Hills, H. Ikram, M. Johnstone, A. Smart; Norway (61) - J. Erikssen, T. Morstel, J. Winther Haerem; Poland (2050) - P. Achremczyk, A. Baranowska, P. Burduk, D. Cichon, A. Czepiel, H. Danielewicz, P. Danielewicz, W. Dworzanski, J. Gessek, A. Gorecki, J. Gorny, K. Janik, A. Jedrzejowski, G. Kania, T. Kawka-Urbanek, J. Klaudel, D. Kopcik, A. Kozlowski, W. Krasowski, A. Ladach, M. Laniec, J. Maciejewicz, P. Maciejewski, Z. Majcher, S. Malinowski, T. Marczyk, P. Miekus, T. Myczka, M. Ogorek, M. Piepiorka, K. Religa, Z. Reszka, M. Rozwodowska, W. Smielak-Korombel, D. Smiglak, J. Spyra, S. Stec, D. Susol, M. Szpajer, P. Szymanski, G. SzumczykMuszytowska, M. Tomzynski, M. Ujda, W. Wasek, T. Waszyrowski, P. Wojewoda, A. Wnorowska, P. Wrobel, J. Zadrozny, A. Zebrowski, Z. Zielinski; Portugal (129) - J.M. Bastos, P. Cardoso, M. Carrageta, C. Catari- no, R Ferreira, M Veloso Gomes; South Africa (308) - A. Aboo, L Bobak, B. Brown, S. Cassim, S. Harripersadh, P. Manga, F. Maritz, J. Marx, D. Myburgh, H. Nell, A. Okreglicki, H. Theron; Spain (330) - N. Alonso Orcajo, F. Colomina, I. Echanove, J. Garcia Guerrero, E. Gomez-Martinez, I. Lekuona, L. Miralles, C. Pasaval, A. Rovira, J. San Jose, A. Rodriguez Llorian, V. Valentin; Sweden (260) - N. Abdon, B. Bartholdson, E. Basilier, I. Johansson, B. Kristensson, K. Larsson, P. Lindell, B. Moller, G. Rasmanis, A. Stjerna, K. Tolhagen; Switzerland (225) - B. Caduff, G. Noseda, A. Rossi, D. Schmidt, J. Zerega; United States (462) - K. Carr, R. Detrano, R. Geer, G. Grewal, P. Hermany, N. Lakkis, W.R. Lewis, T.R. Pacheco, G. Papuchis, J. Puma, S. Runckey, U. Thadani, J. Whitaker; United Kingdom (737) - Y.J.A. Adgey, D. Blackman, M. Brack, A. Bridges, A. Cohen, P. Currie, S. Duffy, I. Findlay, J. Goodfellow, K. Gray, D. Hogg, D. Holdright, D. Hughes, N. Irvine, K. Jennings, P. Keeling, P. Ludman, T. Mathew, P McIntyre, R. Oliver, N. Palmer, E. Rodrigues, L. Smyth, D. Sprigings, J. Stephens, A. Timmis, R. Vincent.

\section{REFERENCES}

1. Yeghiazarians $\mathrm{Y}$, Braunstein JB, Askari A, Stone $\mathrm{PH}$. Unstable angina pectoris. N Engl J Med 2000;342:101-14.

2. Antiplatelet Trialists' Collaboration. Collaborative overview of randomised trials of antiplatelet therapy. I. Prevention of death, myocardial infarc tion, and stroke by prolonged antiplatelet therapy in various categories of patients. BMJ 1994;308:81-106. [Erratum, BMJ 1994;308:1540.]

3. Low-molecular-weight heparin during instability in coronary artery disease. Lancet 1996;347:561-8.

4. The Platelet Receptor Inhibition in Ischemic Syndrome Management in Patients Limited by Unstable Signs and Symptoms (PRISM-PLUS) Investigators. Inhibition of the platelet glycoprotein IIb/IIIa receptor with tirofiban in unstable angina and non-Q-wave acute myocardial infarction. N Engl J Med 1998;338:1488-97.

5. The GUSTO IV-ACS Investigators. Effect of glycoprotein IIb/IIIa re ceptor blocker abciximab on outcome in patients with acute coronary syndromes without early coronary revascularization: the GUSTO IV-ACS randomized trial. Lancet 2001;357:1915-24.

6. Chew DP, Bhatt D, Sapp S, Topol EJ. Increased mortality with oral platelet glycoprotein IIb/IIIa antagonists: a meta-analysis of phase III multicenter randomized trials. Circulation 2001;103:201-6.

7. FRagmin and Fast Revascularisation during InStability in Coronary artery disease (FRISC II) Investigators. Long-term low-molecular-mass heparin in unstable coronary-artery disease: FRISC II prospective randomised multicentre study. Lancet 1999;354:701-7. [Erratum, Lancet 1999;354:1478.]

8. The Organization to Assess Strategies for Ischemic Syndromes (OASIS) Investigators. Effects of long-term, moderate-intensity oral anticoagulation in addition to aspirin in unstable angina. J Am Coll Cardiol 2001;37:475-84 9. CAPRIE Steering Committee. A randomised, blinded, trial of clopidogrel versus aspirin in patients at risk of ischaemic events (CAPRIE). Lancet 1996;348:1329-39.

10. CURE Study Investigators. The Clopidogrel in Unstable angina to prevent Recurrent Events (CURE) trial programme: rationale, design and baseline characteristics including a meta-analysis of the effects of thienopyridines in vascular disease. Eur Heart J 2000;21:2033-41.

11. Rao AK, Pratt $C$, Berke $A$, et al. Thrombolysis in Myocardial Infarction (TIMI) Trial - phase I: hemorrhagic manifestations and changes in plasma fibrinogen and the fibrinolytic system in patients treated with recombinant tissue plasminogen activator and streptokinase. J Am Coll Car diol 1988;11:1-11.

12. The PURSUIT Trial Investigators. Inhibition of platelet glycoprotein IIb/IIIa with eptifibatide in patients with acute coronary syndromes. N Engl J Med 1998;339:436-43.

13. The Heart Outcomes Prevention Evaluation Study Investigators. Effects of an angiotensin-converting-enzyme inhibitor, ramipril, on cardiovascular events in high-risk patients. N Engl J Med 2000;342:145-53. [Erratum, N Engl J Med 2000;342:748.]

14. Yusuf $S$, Wittes J, Friedman L. Overview of results of randomized clinical trials in heart disease. II. Unstable angina, heart failure, primary preven tion with aspirin, and risk factor modification. JAMA 1988;260:2259-63. 15. Tonkin AM, Colquhoun D, Emberson J, et al. Effects of pravastatin in 3260 patients with unstable angina: results from the LIPID study. Lancet 2000;356:1871-5.

16. Anti-thrombotic Trialists Collaboration. Prevention of death, myocar dial infarction and stroke by antiplatelet therapy: collaborative meta-analysis of 266 trials involving 200,000 patients at high risk of occlusive vascular disease. BMJ (in press).

17. The SYMPHONY Investigators. Comparison of sibrafiban with aspirin for prevention of cardiovascular events after acute coronary syndromes: a randomised trial. Lancet 2000;355:337-45.

Copyright (C) 2001 Massachusetts Medical Society. 
CORRECTION

Effects of Clopidogrel in Addition to Aspirin in Patients with Acute Coronary Syndromes without ST-Segment Elevation

Effects of Clopidogrel in Addition to Aspirin in Patients with Acute Coronary Syndromes without ST-Segment Elevation. On page 502, 20 lines from the bottom of the left-hand column, "B. Pontillo" should have been listed as "D. Pontillo." 
CORRECTION

Effects of Clopidogrel in Addition to Aspirin in Patients with Acute Coronary Syndromes without ST-Segment Elevation

Effects of Clopidogrel in Addition to Aspirin in Patients with Acute Coronary Syndromes without ST-Segment Elevation . On page 494, at the end of the Results section of the abstract, the percentages of patients with episodes of life-threatening bleeding should have been "2.2 percent vs. 1.8 percent," not "2.1 percent vs. 1.8 percent," as printed. In the Manuscript Writing Committee listed at the bottom of the right-hand column, "Keith K. Fox" should have read "Keith A.A. Fox." On page 498, on line 13 of the left-hand column, the rates of bleeding after coronary-artery bypass grafting should have read, " 8.3 percent vs. 6.6 percent," not " 1.3 percent vs. 1.1 percent," as printed. 